\title{
Basic Management Functions in Culture and Arts Organisations
}

DOI: 10.7595/management.fon.2016.0024

In the last fifty years management has become a significant factor in the development of sectors that have no profit characteristics. The culture and arts organisations are aware of the need for management. However, various specific aspects of the artistic practice are the key issue regarding the implementation of management in culture and arts. The main problem in obtaining positive outcomes is the correct adjustment of management and art functions having in mind the relationship between the two. The management functions need to be implemented and applied in such a manner that art activities should not be compromised. Due to project orientation, lack of funding and environment changes, entrepreneurship has assumed a significant role in achieving the goals of culture and arts organisations. In less developed countries, the functions of management are not implemented in arts and culture to their full potential. One reason is the importance a given society assigns to arts and culture. Still, implementation of management is the fundamental assumption of faster development of artistic, organisational and technical modernization and financial stabilisation of culture and arts organisations.

Keywords: culture and arts organisations, management functions, development.

\section{Introduction}

In the late nineteenth century, during the Industrial Revolution, manual labour was replaced by the serial production. When productivity and efficiency of production became an ultimate goal, a new discipline, scientific management, emerged (Drucker, 1974; Adizes, 2002; Jovanovic, 2005; Weihrich and Koontz, 2004). In manufacturing industry, management was applied as a scientific discipline. In time, management has became a vital development factor for a number of domains of social life, including areas that are not directly connected to production or profitability, for examole, to culture and arts. Even so, arts and culture are important for the society, so it is vital that arts and culture organisations should be appropriately developed.

Economic development has influence on the development of arts and cultural sectors. Also, specific activities of arts and culture themselves affect the development of this sector. Organizations in culture are mostly labour intensive, so the most important source for achieving a positive outcome is human resources (Varbanova, 2013). However, knowledge should not be neglected, since it is a growing source of competitive advantage in the information age, and arts are especially considered to be knowledge intensive (Schnabl \& Zenker, 2013). The majority of organisations in this area are project oriented. To be successful, organisations apply management function and entrepreneurship. However, in some countries, the functions of management are not implemented in cultural practice to a sufficient extent, which in turn results in an uneconomical use of available resources and in relatively modest outcomes of artistic creativity in comparison with what could be achieved otherwise.

The purpose of this paper is to survey the implementation of basic management functions in culture and arts organisations as well as to analyse the possibility of their implementation towards the development of these 
organisations. The main aim of this paper is to present the position and problems of arts and culture organisations and show how positive changes can be stimulated.

The paper is structured as follows: after the introduction section, Section 2 gives the overview of management in culture and arts organisations. Section 3 presents the implementation of management functions in culture and arts organisations. The last section presents conclusion remarks.

\section{Management in Arts and Culture Organisations}

The first reason for the absence of organisational components in arts can be found in its usual hostility towards economic categories, because art itself traditionally resists the impact of economic laws on its creations. Another reason is a relatively late social recognition of arts as an economic capacity. It is then that economic exploitation of arts began and is still under way (Austin \& Devin, 2010; Rhisiart, 2013). This irreversible flow transformed the realm of creativity into artistic production and aesthetic experience into consumption. Due to that fact, arts are subsidized by the state (Crepaz et al., 2015). The functions, methods and techniques of management have become quite welcome in this area. The key issue regarding implementation of management in culture concerns the basic principles that have to be preserved in order not to compromise the very nature and essence of the creative process. Generally, management in arts should establish a balance among at least three concepts: a) the concept of aesthetics - providing the conditions for the smooth operation of creative artists, support and promotion of evaluating core values of artistic creativity; b) the concept of public interest - the market valuation of the immeasurable contributions of art, the socalled positive externalities; and c) the concept of rationality - conditions for rational and responsible behaviour of all participants, especially as regards the use of material and financial resources (Nikodijevic, 2008). There is an obvious need for a discipline which will model art organizationally but still reflect the essence and creative character of this activity (Nikodijevic, 2006). In this context, cultural management involves the creation of conditions for artistic creativity and production of cultural goods (ideas and values) as well as for their design in the works/objects that are accessible to the public and for their reception in the cultural community (Dragicevic-Sesic \& Stojkovic, 2000).

In the 21st century, there is an enormous need worldwide for a basic knowledge of management in the cultural sector. There are many studies about how to successfully manage commercial businesses, but the literature on managing cultural organisations is comparatively scarce (Hagoort, 2004). The past thirty years have seen a steady increase of publications in arts management. In addition to that, a major scientific conference was organised in 1991 (International Conference on Arts and Cultural Management). Moreover, approximately 400 training programmes in cultural management are offered to institutions around the world. All of these point to the existence of significant research activity and the development of a keen interest in management practices in the arts and cultural sectors (Evrard \& Colbert, 2000).

Management is not independent of the civilisational and cultural context in which it originated and evolved. Firstly, it puts emphasis on the economy, efficiency and productivity, and later to the administrative organisation and a strict division of management. There are two types of management philosophy - European and American. The European management philosophy is oriented towards both the past and the present, and that is characterised by wisdom, stability, respect for conventions, quality and variety. The American management is focused on the future and characterised by vitality, mobility, informality, quantity and good organisation (Evrard \& Colbert, 2000). The observed cultural organisations in Europe only partly depend on changes in the environment. The management of arts has the responsibility not only to respond to that kind of challenge but also to make these changes the agents and promoters of desirable trends. During the transition period Eastern Europe countries have started introducing the principles and methods of cultural management and establishing and developing art market. The goal of such an action is oriented to neutralising the negative aspects and consequences of the transition process in the culture. Opportunities that arts management provides in the development of new initiatives in culture and arts institutions are still not sufficiently taken advantage of (Dragicevic-Sesis \& Dragojevic, 2005). For example, Russian theatres have evolved within a system in which the State has a fundamental role. The changes in the Russian political situation have not affected the objectives of Russian artists or the traditional methods of managing a theatre. The model of publicly funded permanent troupes remains intact (Levshina \& Orlov, 2000). 
Arts organisations are built on multiple tensions between artistic and managerial values. The ability to establish the balance between these two value systems is of key importance to ensuring the viability and longterm survival of the organisation. An arts organisation's strategic plan represents the adjustments of management and art functions having in mind the relationship between the two (Daigle \& Rouleau, 2006). According to Hagoort (2007), for a company whose main driving force is earning profits to qualify as a cultural enterprise, the financial aims must be subordinate to the artistic objectives. However, this does not mean that such a company can be run at a loss (Hagoort, 2013). Besides, management has to balance the entrepreneurial targets with the cultural ones (Hagoort, 2007). Further, the artistic and non-profit character of some cultural institutions is not automatically a precondition and a guarantee of a high artistic quality nor is the orientation to profit doomed to mandatory modest artistic results (Raduski, 2013). For example, the famous musical "Cats" lived on the scene of the commercial "New London Theatre" for over 20 years and had the financial result of over $€ 2$ billion (Nikodijevic, 2008).

Arts organisations are subject to a variety of both internal and external forces that exert pressure on them and drive them to undertake major transformations to ensure their survival. All the performing arts share the same core issues: producing or presenting artistically satisfying works in accord with their missions, finding and keeping an audience, providing for the financial and creative well-being of an organisation or production, and maintaining good personnel and public relations (Conte \& Langley, 2007). Managerial personnel in arts operations, although dealing with the fine arts, concerned with creativity, audience appreciation and good art, can benefit from models contributed by management science. Managers, production coordinators and department chairmen in arts organisations perform numerous tasks similar to those of managers in government bodies and industry (Bhansing et al., 2012; Reid, 2014). As a result of the constantly changing environments, the key to being a good manager in any field is much more than simply knowing "what to do". It needs to know "why to do what to do" - the theoretical foundations and fundamental principles that drive managerial actions. When "what to do" stops working, those basic concepts will help understand "why to do". It is these concepts that will characterise the manager's efforts to address the new conditions (Byrnes, 2009).

Production in arts organisations differs from that in manufacturing companies. Arts production, as opposed to industrial production, is characterised by a very high share of the costs of direct human labour, and the economic benefit is limited by way of placement. Industry has control over the inventory of raw materials and final goods, which is hardly possible in the domain of arts. Opposite to commercial activities, in most of the arts, there is no mass production, which is an essential characteristic of the economy (Nikodijević 2008). "In standard manufacturing, management focuses on creating such a form of activity that leads to the production of larger effects, while in the domain of culture and arts, management's main task is to create conditions that will allow consistent and uninterrupted creative work on the design and realization of some piece of art" (Muzdeka-Mandzuka, 2000).

Entrepreneurship is one of the factors of development in each industry. There are various definitions of entrepreneurship in cultural and creative industries. Hagoort (2007) uses the term "cultural entrepreneurship". Cultural entrepreneurship is the process of integrating two freedoms: artistic freedom as an immaterial content-oriented value, and entrepreneurial freedom as the material value, supportive to immaterial (cultural) values. In essence, a cultural entrepreneur can be described as someone who creates a cultural product or service and who uses entrepreneurial principles to organise and manage a creative activity in a commercial manner (Hagoort, 2004).

Therefore, the implementation of academic and practical knowledge of management functions, methods and techniques is one of the fundamental assumptions of faster artistic and economic development of all cultural institutions. However, all specific features, multidisciplinarity and unpredictability of scenic production should be recognised, and commercialization should not violate the basic principles of artistic creation. "Since the twentieth century, the act of creation of an art work has no longer been an individual act but has become more and more inseparable from money and politics" (Molar, 2000). Contrary to this, "the purpose of nonprofit arts institution is to enable the artists to create and convey their creations to the entire society, by their artistic awareness and conscience" (Adizes, 2002). Further, the arts manager's purpose is to help an organisation and its artists to realise the organisational vision and fulfill their mission (Byrnes, 2009). 


\section{Management Functions in Culture and Arts Organisations}

According to management theory, there are five basic management functions: planning, organising, staffing, leading and controlling (Jovanovic, 2005). Drucker (1974), through an approach based on business objectives, singled out four basic functions of management: goal setting; organisation; motivation and communication; and finally measurement and assessment of results. Cole (2003) sees only four management subprocesses: planning, organising, motivating and controlling. Similarly, Byrnes (2009) handles the content order by organising the cultural management process into four traditional management functions: planning, organising (including staffing), leading (or directing), and controlling.

The quality of planning is the precondition for the execution of other functions of management and management in general (Jovanovic, 2005). Planning requires the presence of purpose, objectives, strategies and policies (Weihrich \& Koontz, 2004). "Planning is essentially a decision-making process that focuses on the future of the organisation and how it will get where it wants to go" (Stewart Black \& Porter, 2000). Planning in culture is a process of predicting activities necessary for the production of the art performances of as high artistic quality as possible, whether these are long-term, global plans (strategic planning of goals to be achieved) or short-term, operational plans (how these goals are to be achieved). Namely, a long-term plan is a basis upon which annual and monthly plans are designed thereby making the execution of art projects considerably more operational (Lukic, 2011). The annual plan includes four separate constituent parts: financial, program, investment and personnel plans that are executed in just the above-quoted order.

Planning in culture has to be dynamic and flexible. It may be made additionally complicated and hindered by the unpredictability of the art production itself, by numerous improvisations in work that are characteristic of artistic industry, as well as by the impact of the human factor. On the other hand, planning in culture serves to anticipate the future tasks and activities classified into phases and procedures, to determine the necessary personnel, material and technical and financial resources. All this is accomplished without entering the artistic domain, except in the sense of flexible planning of the period in which certain artistic activities will be performed (Lukic, 2011). Planning should begin with the preparations for the project plan creation, with the strategic plan, and then proceed to create a concrete production plan as a synthesis of all organisational, technical and technological, personnel, economic and other activities required for its execution. Here it may be efficient to divide the production plan into smaller-scope plans, such as partial production plans, procurement plan, placement plan, promotion plan, etc. In the planning (and, later, monitoring) process, the manager has various techniques at his/her disposal; most frequently used are gantograms that visually present the time plan for the realisation of concrete activities.

Finally, planning in culture and arts is not a simple job, partly due to a significant impact of subjective factors about the creators themselves and the nature of artistic production, and partly due to a changing nature of the audience as consumers. Planning is necessary at all the levels of activities and in all organisational sectors. It is a task of all the managers in the cultural organisation, which requires from them a certain extent of knowledge and competence. This, however, is not a regular practice in Serbia. In defining plans, arts managers frequently avoid the usual procedure; they do not set long-term objectives, they fail to analyse realistic opportunities, potentials and obstacles, they fail to analyse the environment and external effects, to explore alternatives. Especially lacking are detailed analyses of necessary and available resources, primarily financial.

Organizing is a set of activities applied to establish functional relations among components of the process in order to obtain the set goals (Jasko et al., 2013). This includes job delegation, grouping, linking and precisely defining individual tasks, methods of work, authority and responsibility to which organisation and planning are directly related, although the once established organisation is not taken to last forever (Jovanovic, 2005). Thus all the resources are put to work and relations between activities and people are determined so that they should operate as one whole (Weihrich \& Koontz, 2004).

Cultural and arts organisations in Serbia are required by the law to adopt statutes defining the internal organisation structure, the division into sectors according to their respective activities and grouping of jobs into functional units, whereas a rulebook on job classification specifies the individual division of labour. In practice, a divisional organisational structure prevails. For example, the existing organisational model in the theatres in this country usually includes three basic sectors - the arts sector, the technical sector and the sector of general affairs, and is established on a traditional, functional organisational structure (Raduski, 2012). 
This institutional model does have certain advantages, e.g., direct management and control of the incumbents' work. However, it also has numerous flaws: overlapping of resources, dysfunctional horizontal communication (Delic, 2003) and, most importantly, too high production maintenance costs (Sailovic, 2004). Modern European experience is a far better solution in case of the art industry. It is a project organisation that has a matrix organisational structure that enables networking of all functional units and team work in the execution of art projects (Mandzuka-Muzdeka 2000). Organisations with the matrix structure last as long as the project itself lasts, whereas functional units are dislocated to the project level with one part of their resources and they return to their respective institutional positions upon the completion of the project. The divisional organisational structure is neither flexible nor rational, whereas modern arts organisations need a concept that is characterised by the capability of prompt changes, managerial team work, openness to new ideas and an interactive relationship with clients (Zdravkovic, 2006). That is why the transition from the institutional to the project logic is one of the initial steps in the reform of the cultural industry model in the Eastern Europe countries.

One type of organising focuses on setting an efficient system and interaction of its components, where the project manager, following the principles of project management and matrix organisational structure, assigns jobs to organisational sectors (vertical structure) and concrete incumbents (horizontal structure) (Lukic, 2011). Organisation of production in the culture and arts organisations is best illustrated by a definition that describes the capability of organising as a "skill of making common people achieve uncommon results" (Ridderstrale \& Nordstrom, 2002).

The staffing (or recruitment) function allows for the first two functions of management to come into life and be executed in practice since there is no management without people. This is a function of attracting, selecting, training, allocating, replacement, assessment and rewarding of personnel (Jovanovic, 2005). There are some specific features of human resource management in arts organisations because human resources have to be appropriately planned and managed. Some of the specific features of human resources are a diversity of characters of teams, high specialisation of the art sector; the particular requirement is that art organisation should be flexible and project oriented, etc. (Varbanova, 2013). To summarise, the area of culture is especially sensitive when it comes to the human resource policy level. A proper assignment of artistic tasks is crucial for the success of any arts product.

Cultural organisations in Serbia, however, do not pay due attention to the human resource policy, except in the domain of assignment of artistic roles and tasks (Sailovic, 2004). So, the work of human resource departments is often confined to keeping records on the personnel and tracking the data in the area of labour relations. In case recruitment is conducted in an unplanned and inexpert manner, which is a rather common practice in this country, it has a negative effect both on the artistic performance as measured by the attitudes of the audience and critics, and on the earnings and the overall business results (Raduski, 2013). Further, the first step in the upcoming reform of the cultural system in Serbia has to be related to the human resource policy itself. This is for the purpose that in the future, at least in the case of artists, labour contracts will be signed for a fixed period of time or by closing separate authors', performers' or other contracts for a particular project. This would result in significant reduction of budgetary funds for the gross earnings of the employees, thereby a larger amount of the founder's funds remains to be allocated to art production. The Law on Culture (2010) sets the preconditions for the rationalisation of the number of employees in arts organisations by fixed-term employment contracts, per project, up to three years, with the possibility of renewal. The article 50 of the Law was subsequently contested by the cultural profession itself (Raduski, 2012). Such a rationalisation of the number of employees does not mean that the arts organisations will lose permanent ensembles. Even without a permanent employment contract, the artists can be engaged for certain seasons, on one or several projects, a contract that may be renewed depending on their artistic reputation and the organisation's needs (Raduski, 2013a).

The fourth function of management is leading where managers make an efficient use of human resources, guide and coordinate personnel in their accomplishment of their respective assigned tasks, which includes a two-way communication between the manager and the employees, the employee motivation, with a continual monitoring and assessment of work outcomes, employee training and development, and a continual decision making in any phases and aspects of guidance (Jovanovic, 2005). The quality of the decisions can be measured through their functionality (whether they produce the desired result), and efficient implementation of the efforts made to achieve the goal (invested time and money and human labour). Only a good decision and its efficient implementation can lead to positive outcomes. According to Adizes (2002) "what 
is necessary to make a quality decision are not perfect individuals, but the complementary team. To carry out a decision, there must be a unity of interest between people, a formal authority, power and influence based on professional competence" (Nikodijevic, 2006). Managers in culture and arts organisations base their strategic and operating decisions upon fulfilment of the mission statement and these organisational values and the strategic orientation affect firm performance (Giraud-Voss \& Voss, 2000).

Management requires that the manager should collaborate with all the people included in the art projects, having in mind the structure and the complexity of every performance. Due to various specific features of artistic practice and specific traits of artists themselves, success depends on the leadership skills of the management staff - primarily of the producer, top manager, division manager. Further, an essential role in obtaining success is performed by the functional units that direct and coordinate the accomplishment of concrete tasks, that assign jobs, define the method of their execution, monitor the performance and undertake appropriate measures when necessary. Byrnes (2009) said: "Our responsibilities as arts managers within the not-for-profit sector are daunting. Internally, we are charged with providing an atmosphere for artists to develop and realise their visions with resources that would otherwise be unavailable - or, at least, greatly diminished - if left to the pressures of the traditional free-market system."

The last function of management is controlling, a complex and lasting process that involves a large number of activities oriented towards analysing and checking whether the execution proceeds as planned, identifying possible deviations and eliminating them along the way (Jovanovic, 2005).

All the subsidised cultural institutions throughout the world, some of those privately owned, are supervised. This is a result of a need to control the spending of financial assets during the programme and other activities, for the purpose of protection of interests of the founder, the social community and the employees (whose representatives are members of the boards of directors) (Lukic, 2011). In Serbian arts practice, the major type of control is the annual report that organisations submit to their founder, listing the programs delivered and explaining the use of the allocated funds. Here is also included a statutory activity of a supervisory board in the areas of finance and legality, whereas there are no regulated standards by which the top management will be in a position to control the success and the quality of work at the lower organisational levels. For example, the control function in Serbian theatres is present almost exclusively on the project level, primarily on the artistic plan (Sailovic, 2004).

\section{Conslusion}

Given the attitudes of the competent representatives of the cultural and professional economic public, it can be concluded that the development of culture and arts organisations depends on economic development and the society's will for developing those organisations. Accordingly, problems in cultural industry are related to funding, management and organisation of work, as well as to the lack of a long-term plan for development. However, if the society decides that art is important for it, the state can enhance the culture and arts development through funding it (Crepaz et al., 2015).

Strategic planning of arts and culture organisations is a process of adjustment of management and art functions having in mind the relationship between the two. In the majority of cases, these organisations are project oriented. Due to lack of funding, entrepreneurship becomes increasingly important for arts and culture organisations. Neglecting modern management in culture and arts organisations results in non-profitable business, an uneconomical use of available resources and relatively modest artistic outcomes in comparison with what can be achieved with the present personnel, material and financial resources. Contrary to this, implementation of the management functions can enable a more efficient and effective business, the economic and financial stability of the arts organisations, a fast organisational and technical modernisation, staff and artistic development and higher creative achievements in the cultural and art production. 


\section{REFERENCES}

[1] Adizes, I. (2002). Menadzment za kulturu, Asee books, Novi Sad

[2] Austin, R. D. and Devin, L. (2010). Not just a pretty face: economic drivers behind the arts-inbusiness movement, Journal of Business Strategy, 31(4), 59 - 69.

[3] Bhansing, P.V., Leenders, M.A.M, Wijnberg, N.M. (2012). Performance effects of cognitive heterogeneity in dual leadership structures in the arts:The role of selective system orientations. European Management Journal, 30 (6), 523-534.

[4] Byrnes, W. (2009). Management and the Arts. Focal Press. Burlington.

[5] Cole, G. A. (2003). Management: Theory and Practice, DP Publication, London.

[6] Conte, D. M. and Langley S. (2007). Theatre Management: Producing and Managing the Performing, ArtsEntertainmentPro, New York.

[7] Crepaz, L., Huber, C., Scheytt,T. (2015). Governing arts through valuation: The role of the state as network actor in the European Capital of Culture 2010. Cricital Perspecitves on Accounting, 37, 35-50.

[8] Daigle P. and Rouleau L. (2006). Strategic Plans in Arts Organizations: A Tool of Compromise Between Artistic and Managerial Values. International Journal of Arts Management, 3.

[9] Delic, A. (2003). Upravljanje nacionalnim pozorištem primenom savremenog menadzmenta, na primeru Narodnog pozorišta u Beogradu, magistarski rad, FDU, Beograd,

[10] Dragicevic-Sesic, M. and Dragojević, S. (2005). Menadzment umetnosti u turbulentnim okolnostima organizacioni pristup, Clio, Beograd.

[11] Dragicevic-Sesic, M. and Stojkovic, B. (2000). Kultura - menadžment, animacija, marketing, Clio, Beograd.

[12] Drucker, P. (1974). Management, Harper and Row Publichers, New York,

[13] Evrard, Y. and Colbert, F. (2000). Arts Management: A New Discipline Entering the Millennium?. International Journal of Arts Management, 2

[14] Giraud-Voss, Z. and Voss, G. B. (2000). Exploring the Impact of Organizational Values and Strategic Orientation on Performance in Not-for-profit Professional Theatre, International Journal of Arts Management, 3.

[15] Hagoort, G. (2004). Art Management: Entrepreneurial style, Eburon Publisher, Utrecht.

[16] Hagoort, G. (2007).Cultural Entrepreneurship: On the Freedom to Create Art and the Freedom to Enterprise, Utrecht University, Utrecht.

[17] Hagoort, G. (2013) Art and entrepreneurship, Nätverkstan, Utrecht.

[18] Jasko, O., Cudanov, M., Jevtic, M., \& Krivokapic, J. (2013). Osnovi organizacije i menadžmenta. FON, Beograd.

[19] Jovanovic, P. (2005). Menadzment - teorija i praksa, Fakultet organizacionih nauka, Beograd.

[20] Jovanovic, P. et.al. (2012). Primena projektnog menadzmenta u upravljanju organizacionim projektima. Management, 64. 69-76.

[21] Levshina E. and Orlov Y. (2000) General and Specific Issues in Russian Theatre International Journal of Arts Management, 2.

[22] Lukic, D. (2011). Produkcija i maketing scenskih umetnosti, HC-IT, Zagreb.

[23] Mandzuka-Muzdeka D. (2000). Projektna organizacija u pozorištu, Omega plus, Beograd.

[24] Molar, K. (2000). Kulturni inzenjering, Clio, Beograd.

[25] Nikodijevic, D. (2008). Menadzment u pozorišnoj delatnosti, Megatrend univerzitet, Beograd.

[26] Nikodijevic D. (2006). Uvod u menadzment kulture, Megatrend univerzitet, Beograd

[27] Raduski, D. (2013). Kulturni menadzment kao faktor razvoja pozorišne delatnosti. Zbornik Matice srpske, 48,167-178.

[28] Raduski, D. (2013a). Kulturni menadzment i marketing kao faktor razvoja pozorišne delatnosti u Beogradu", Megatrend Review, 2, 289-308.

[29] Raduski, D.(2012). Ekonomski polozaj, organizaciono-finansijska transformacija i pravci razvoja pozorisnog sistema Beograda u periodu tranzicije, doktorska disertacija, Megatrend univerzitet, Beograd.

[30] Reid, W. (2014). Artists and Managers as Executive Leaders of Arts Organizations. Kultur und Management. 197-207.

[31] Ridderstrale, J. and Nordstrom, K. (2002). Funks Business, Differo, Zagreb.

[32] Rhisiart, M. (2013). Exploring the future for arts and culture organisations through scenarios and vignettes. Futures, 50, 15-24. 
[33] Sailovic, S. (2004). Novi oblici organizovanja i finansiranja institucionalnog pozorišta u skladu sa principima projektnog menadzmenta na primeru pozorišnog sistema Beograda, magistarski rad, FDU, Beograd.

[34] Schnabl, E. and Zenker, A. (2013). Statistical classification of knowledge-intensive business services (KIBS) with NACE Rev. 2. Fraunhofer ISI.

[35] Stewart Black, J. and Porter, L.W. (2000). Management: Meeting New Challenges, Prentice Hall, New Jersey.

[36] Varbanova, L. (2013). Strategic Mangement in the Arts. Rouledge.

[37] Weihrich, H. and Koont, H. (2004). Management, a Global Perspective, Mc Grawhill, New York.

[38] Zdravkovic, M. (2006). Savremeni menadzment u pozoristu, Zbornik radova FDU,10, 15-22.

Receieved: September 2016. Accepted: December 2016.

\section{$1 / / / / / / / / / / / / / / / / / / / / / / / / / / / / / /$ about the Author}

\section{Faculty of Project and Innovation Management, Belgrade}

Doc. dr Dragoljub Raduški is an assistant professor at the Faculty of Project and Innovation Management in Belgrade (Educons University), where he teaches Project management. His main research interests lie in the field of cultural management, where

he focuses on project management in the theatre. He graduated at the Faculty of

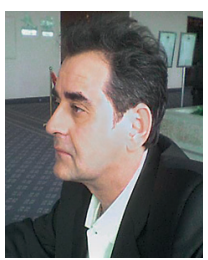
Economics (University in Belgrade), holds an MA degree at the Faculty of Dramatic Arts

(University of Arts in Belgrade) and a PhD at the Faculty of Culture and Media

(Megatrend University in Belgrade). Until now, he has published one book and a number of sientific and research papers in his field of profesional expertise. 